\title{
Evolution of the HIV-1 nef gene in HLA-B*57 Positive Elite Suppressors
}

\author{
Maria Salgado ${ }^{1}$, Timothy P Brennan ${ }^{1}$, Karen A O'Connell ${ }^{1}$, Justin R Bailey ${ }^{1}$, Stuart C Ray ${ }^{1}$, Robert F Siliciano ${ }^{1,2}$, \\ Joel N Blankson ${ }^{1 *}$
}

\begin{abstract}
Elite controllers or suppressors (ES) are HIV-1 infected patients who maintain viral loads of $<50 \mathrm{copies} / \mathrm{ml}$ without antiretroviral therapy. CD8+ $T$ cells are thought to play a key role in the control of viral replication and exert selective pressure on gag and nef in HLA-B*57 positive ES. We previously showed evolution in the gag gene of ES which surprisingly was mostly due to synonymous mutations rather than non-synonymous mutation in targeted CTL epitopes. This finding could be the result of structural constraints on Gag, and we therefore examined the less conserved nef gene. We found slow evolution of nef in plasma virus in some ES. This evolution is mostly due to synonymous mutations and occurs at a rate similar to that seen in the gag gene in the same patients. The results provide further evidence of ongoing viral replication in ES and suggest that the nef and gag genes in these patients respond similarly to selective pressure from the host.
\end{abstract}

\section{Findings}

The mechanisms responsible for the control of the HIV1 replication in elite suppressors are not fully understood [1-3]. Replication competent virus has been isolated from some ES [4-6] and genotypic [4], phenotypic [4], and epidemiologic [7] analyses have suggested that these isolates are generally fully pathogenic. Thus it appears that in many cases, host factors rather than infection with defective virus are responsible for the elite control of viral replication. The HLA-B*57 allele is overrepresented in ES [8-14] which suggests an important role of CD8+ T cells. These cells have been shown to exert selective pressure on HLA-B*57 restricted epitopes in ES [15-17] and LTNPs [18], and we have previously documented evidence of evolution in the gag gene in plasma virus of HLA-B*57 positive ES over a 5 year period [19]. However, some studies have suggested that Gag is preferentially targeted by CD8+ $\mathrm{T}$ cells in patients who control viremia $[12,20]$ and it is therefore possible that viral evolution in ES is limited to this gene. To test this hypothesis, we analyzed proviral and plasma nef sequences in ES over a 6 year period and compared the rate of evolution in these two

\footnotetext{
* Correspondence: jblanks@jhmi.edu

'Department of Medicine, Johns Hopkins University School of Medicine. 733 N. Broadway, Baltimore MD 21205, USA

Full list of author information is available at the end of the article
}

compartments to the rate of evolution of observed for the gag gene.

Four previously described HLA-B*57 ES patients were studied [16,21]. Viral RNA was isolated from plasma, and genomic DNA was purified from resting CD4+ T cells as described previously [16]. To limit PCR resampling, nef genes were amplified from provirus in genomic DNA and from plasma-derived RNA by limiting dilution "digital" nested PCR using previously described primers and conditions [21]. PCR products were directly sequenced using an ABI PRISM 3700 DNA analyzer (Applied Biosystems). Chromatograms were manually examined for the presence of double peaks indicative of two templates per sequencing reaction. Such sequences were discarded. Sequences were assembled using CodonCode Aligner, version 1.3.1, aligned using ClustalX, and the alignments were manually adjusted in Bioedit. Sequences were translated in Bioedit, and the mean number of amino acid differences between all provirus nef and all plasma virus nef sequences from each patient was calculated.

\section{Phylogenetic analysis and statistics}

All independent clonal sequences obtained were included in the phylogenetic analysis, with the exception of sequences showing APOBEC3G/F-mediated hypermutation, which were removed. Sequences [GenBank: FJ430356 to FJ430471 and HQ448774 to HQ448852]
C Biomed Central

(c) 2010 Salgado et al; licensee BioMed Central Ltd. This is an Open Access article distributed under the terms of the Creative Commons Attribution License (http://creativecommons.org/licenses/by/2.0), which permits unrestricted use, distribution, and reproduction in any medium, provided the original work is properly cited. 
subsequently were handled as previously described [19]. Classical, maximum-likelihood, and Bayesian phylogenetic reconstruction for each patient was performed as previously described [19]. Non-synonymous and synonymous p-distance calculations and the number of differences were based on the Nei-Gojobori method [22] and were calculated by comparing grouped sequences from the early time points in each patient to sequences from the later time points using MEGA 4.0 software [23].

We performed a longitudinal analysis of viral sequences in 4 ES HLA-B*57+ patients in order to determine whether viral evolution occurred in nef. A median of 12 independent nef clones (range 3 to 17) were amplified from plasma virus of each of the four ES. In three patients, we also amplified a median of 9 nef sequences from proviral DNA in resting CD4+ $\mathrm{T}$ cells (range 6 to 16). These new sequences were compared to sequences obtained from the patients 5 to 6 years earlier.

A marked discordance between plasma and proviral sequences was seen at the HLA-B*57 restricted epitope KF9 (Nef 82-90) in ES3 and ES8 (Figure 1). In both patients, the majority of the plasma clones were different at 2 or 3 amino acids from the majority of the proviral clones. There was no evidence of discordance in this epitope in ES7 and ES9 or at the other 2 HLA-B*57 restricted epitopes in any patient, but we continued to see a previously described escape mutation (Q107R) in an undefined epitope in plasma clones in ES3 (KG15, Nef 105-119) [21]. This mutation was not seen in proviral clones. While there was discordance between plasma and proviral clones at both early and late time points, there did not appear to be significant evolution in any of the epitopes in either compartment over a 6 year period.

In order to determine whether evolution was occurring in other regions of the gene, phylogenetic analyses were performed. As shown in Figure 2, there was a striking segregation of plasma and proviral nef sequences for all 4 patients. Proviral sequences from all time points were clustered together and were clearly ancestral to plasma clones from all time points. Furthermore, in ES9 and to a lesser extent ES8, some or all of the plasma clones obtained in 2004 or 2005 (year 0 and 1 respectively) were ancestral to those obtained in 2007 (year 3) and 2010 (year 6). A clear pattern was not seen for ES3 and ES7, possibly due to the lower number of clones available from these patients. The fact that proviral clones were generally ancestral to plasma clones is consistent with the model that proviral clones represent archived HIV-1 in latent reservoirs. As with gag [19], there is little re-seeding of the latent reservoir by plasma nef clones in ES.
In order to further elucidate the observed evolution seen in plasma clones in some ES, we used the Nei-Gojobori method to compare the p-distances of non-synonymous and synonymous mutations between early and late plasma and proviral sequences (Figure 3). This parameter normalizes the frequency of substitutions to the number of possible synonymous or non-synonymous sites, permitting comparisons between the two. Figure 3A shows that synonymous mutations were a more significant factor in the divergence of plasma virus than were non-synonymous mutations in all 4 patients. The same finding was seen with proviral sequences (Figure 3B). We also calculated the number of differences between early and late plasma and proviral sequences in these patients (Figure $3 \mathrm{C}$ and $3 \mathrm{D})$. Very few changes were seen in proviral sequences and there were comparable levels of synonymous and non-synonymous mutations. In some cases this may have been partially due to a low level of plasma virus entering the latent reservoir. In contrast, there were more changes seen in plasma virus and these were mostly synonymous mutations. Taken together, these data illustrate that overall there is significantly more synonymous mutation than non-synonymous mutation and that mutations are more frequent in the plasma virus than in the provirus.

We have previously characterized $\mathrm{CD} 8+\mathrm{T}$ cell responses to Gag [16] and Nef [21] for all 4ES. A median of only 1.5 epitopes in Nef were recognized, the majority of which were HLA-B*57 restricted. A similar pattern was seen in Gag with a median of 3.5 epitopes recognized in this protein, most of which were also HLA-B*57 restricted. To determine whether selective pressure exerted by these $\mathrm{T}$ cell responses on these epitopes resulted in comparable levels of evolution, we compared the p-distances for nef to those we previously calculated for gag (Figure 4). The same pattern of a predominance of synonymous mutations was seen in the two genes with a much higher degree of evolution seen in plasma clones (Figure 4A) than proviral clones (Figure 4B). Furthermore, the p-distances were similar in the gag and nef genes for all $4 \mathrm{ES}$, suggesting that comparable degrees of evolution have occurred in the two genes.

There is substantial evidence that HIV-specific CD8+ $\mathrm{T}$ cells that are ES are functionally superior to those found in patients with progressive disease [13,24-28]. Some studies suggest that Gag is preferentially targeted in patients who control HIV-1 viremia $[12,20]$ and others have shown that Gag-specific CD8+ T cells are better at inhibiting viral replication than $\mathrm{T}$ cells that target Nef [27]. Gag has structural constraints that limit the rate of virologic escape. Also, mutations in some Gag HLA-B*57-restricted epitopes occur at a substantial fitness cost $[29,30]$, leading to reversion to wild type sequence when mutants are transmitted to HLA-B*57 


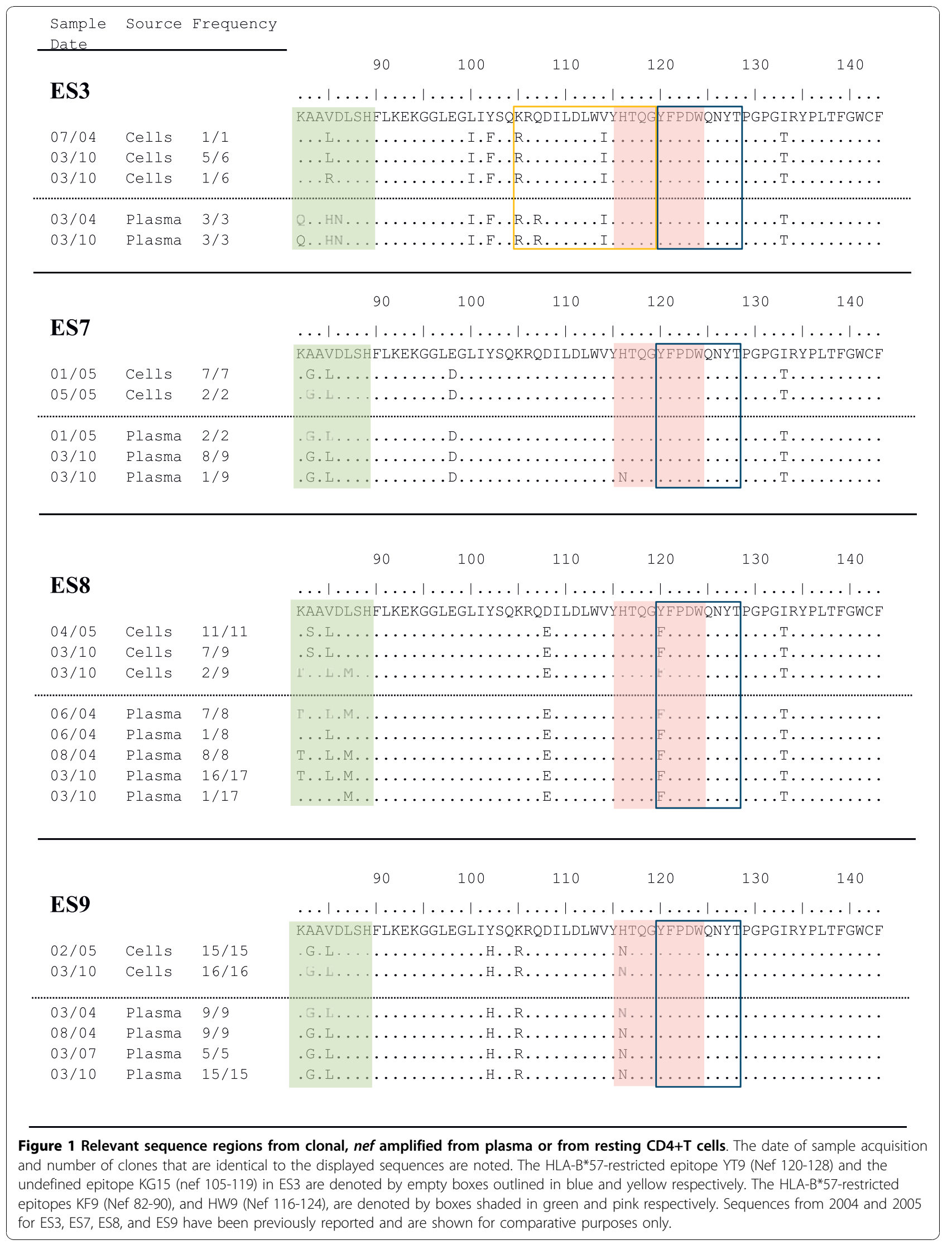




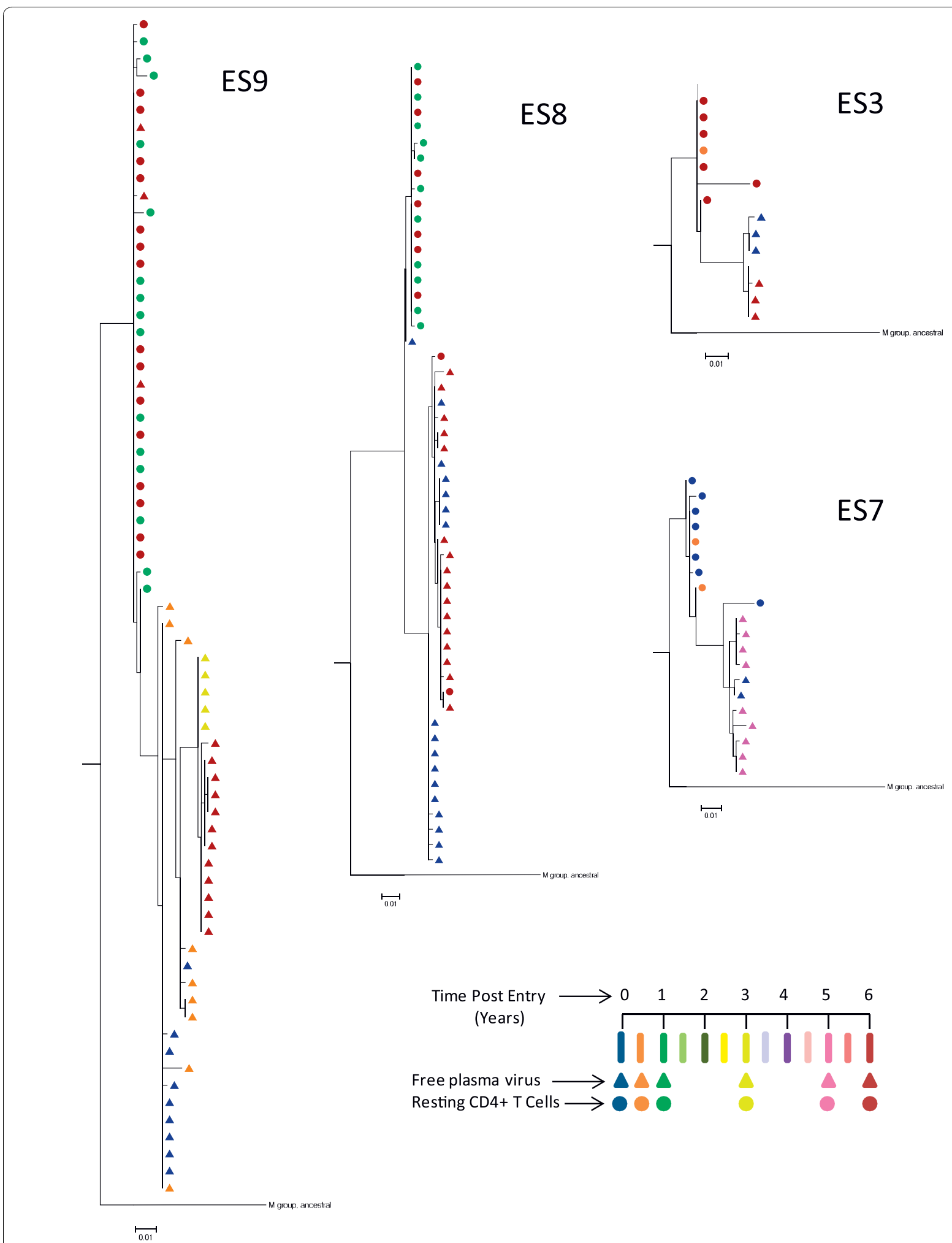

Figure 2 Phylogenetic analysis of nef in the 4 elite suppressor patients. Phylogenies were estimated by using a "classical" approach, functioning under maximum-likeluhood (ML) optimality criterion. All sequences are clonal, and APOBEC-mediated hypermutated sequences were removed from analysis. Colors indicate time, with the scale below in years. Triangles represent clonal plasma sequences, circles represent proviral sequences from CD4+ resting T cells. 
a)

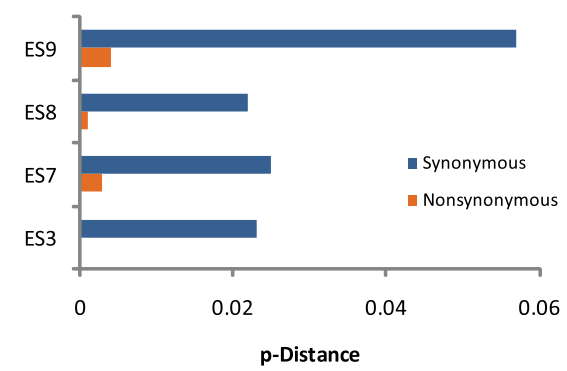

c)

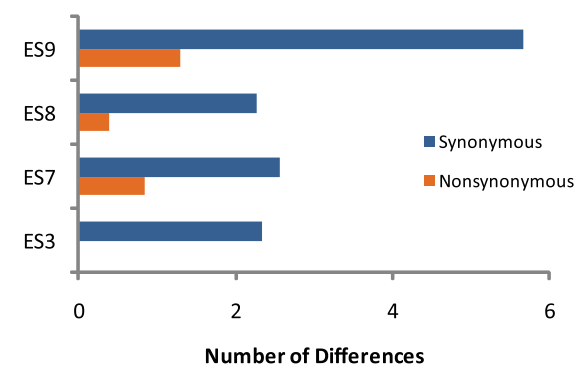

b)

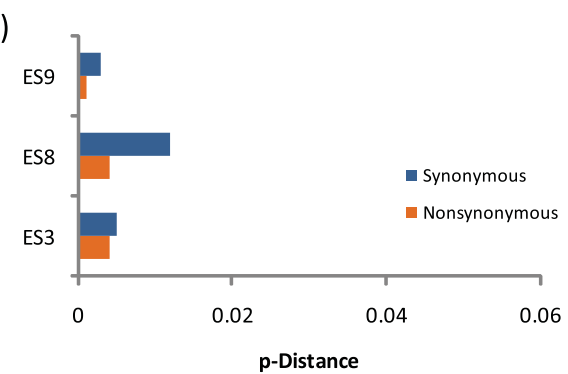

d)

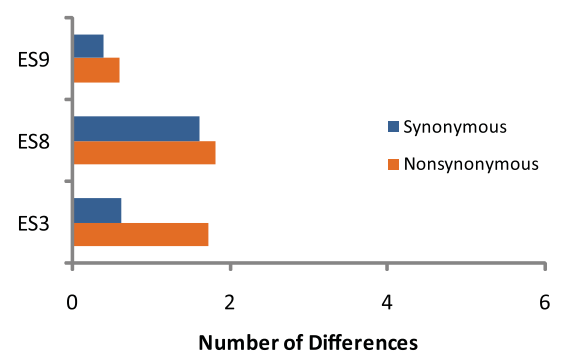

Figure 3 Analysis of synonymous and non-synonymous mutation in the plasma virus and proviral compartments. Shown are p-distance values for plasma (A) and proviral (B) sequences as determined by comparing early and late samples for each patient utilizing the Nei-Gojobori method. The numbers of differences also were calculated for plasma (C) and proviral (D) sequences using the Nei-Gojobori method.
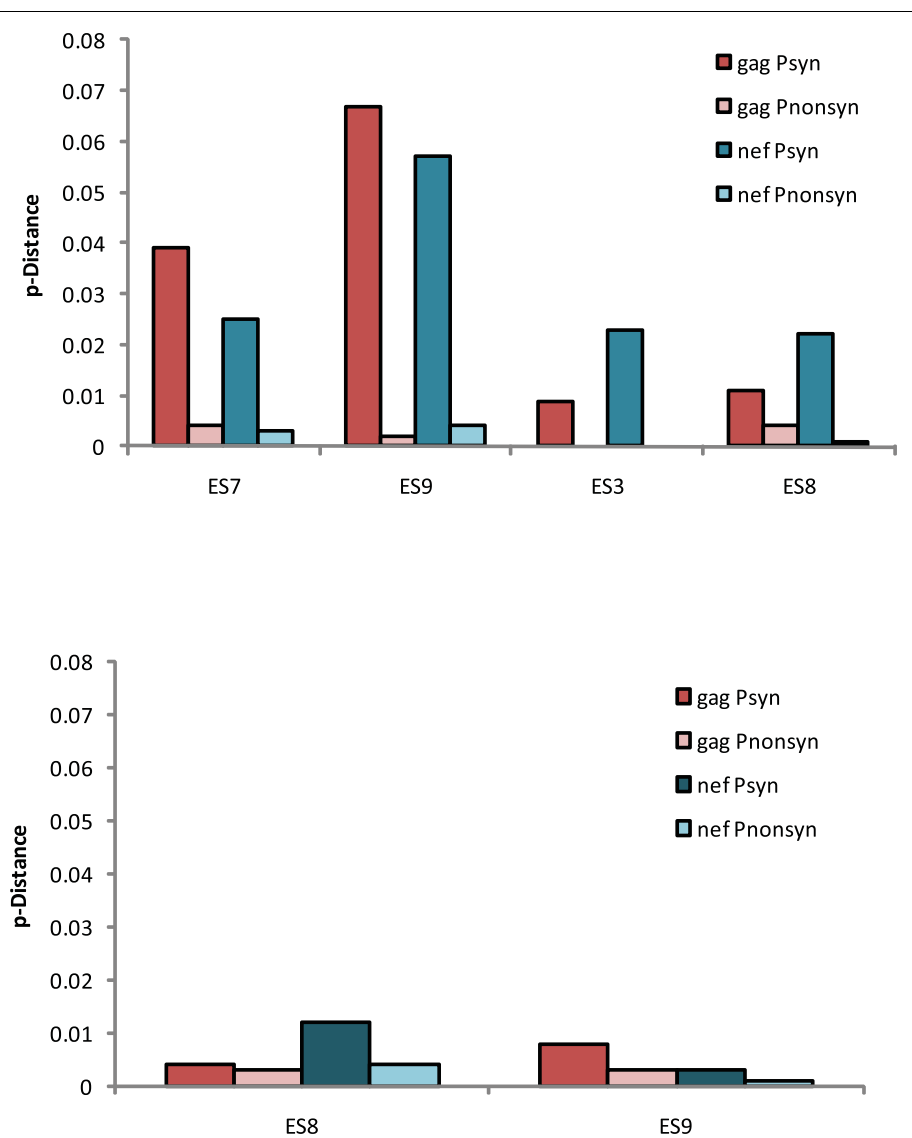

Figure 4 Comparison of synonymous and non-synonymous mutations in nef and gag for plasma (top panel) and proviral (bottom panel) clones. P-distance values were calculated for each patient utilizing the Nei-Gojobori method. 
negative individuals $[31,32]$. In contrast, Nef is less constrained and there is not as much evidence for diminished fitness of escape variants. In fact, in one study, mutations in the Nef KF9 epitope did not revert to wild type following transmission to HLA-B*57 negative patients [33].

We have previously shown that CD8 $+\mathrm{T}$ cells exert selective pressure on both Gag [16] and Nef [21] in plasma virus. We also recently documented evolution in the gag gene in plasma virus in ES [19]. This evolution was mostly seen in regions outside of epitopes and was due to synonymous mutations. We hypothesized that the lack of non-synonymous mutations was a result of the structural constraints on Gag. One would thus expect to see a higher rate of non-synonymous mutations in Nef. However, in all four patients, we saw very few non-synonymous mutations and a comparable frequency of synonymous mutations in both genes. This analysis is technically challenging because it involves the amplification of multiple clonal sequences from plasma and resting CD4+ $\mathrm{T}$ cells of patients who often maintain viral loads of $<1 \mathrm{copy} / \mathrm{ml}[13,34-36]$. The results suggest that in both Gag and Nef, after early virologic escape occurs, there is little continuing evolution in epitopes as a balance between immune evasion and viral fitness is achieved. However, non-synonymous mutations accumulate in both genes in plasma virus as a result of low level ongoing replication. This finding may have implications for the design of HIV-1 vaccines.

\section{Acknowledgements and Funding}

This work was supported by NIH Grant R01 Al080328 (JNB) and the Howard Hughes Medical Institute (RFS)

\section{Author details}

${ }^{1}$ Department of Medicine, Johns Hopkins University School of Medicine. 733 N. Broadway, Baltimore MD 21205, USA. ${ }^{2}$ Howard Hughes Medical Institute. Johns Hopkins University School of Medicine. 733 N. Broadway, Baltimore MD 21205, USA.

\section{Authors' contributions}

MS carried out the molecular genetic studies, participated in the sequence alignment and drafted the manuscript. TPB performed sequence analysis. KAO and JRB carried out the molecular studies. SCR performed sequence analysis and participated in study design. RFS participated in study design and helped to draft the manuscript JNB conceived of the study, and participated in its design and coordination and helped to draft the manuscript. All authors read and approved the final manuscript.

\section{Competing interests}

The authors declare that they have no competing interests.

Received: 26 September 2010 Accepted: 8 November 2010 Published: 8 November 2010

\section{References}

1. Baker BM, Block BL, Rothchild AC, Walker BD: Elite control of HIV infection: implications for vaccine design. Expert Opin Biol Ther 2009, 9(1):55-69.

2. Blankson JN: Effector mechanisms in HIV-1 infected elite controllers: highly active immune responses? Antiviral Res 2010, 85(1):295-302.
3. Migueles SA, Connors M: Long-term nonprogressive disease among untreated HIV-infected individuals: clinical implications of understanding immune control of HIV. JAMA 2010, 304(2):194-201.

4. Blankson JN, Bailey JR, Thayil S, Yang HC, Lassen K, Lai J, Gandhi SK, Siliciano JD, Williams TM, Siliciano RF: Isolation and characterization of replication-competent human immunodeficiency virus type 1 from a subset of elite suppressors. J Virol 2007, 81(5):2508-2518.

5. Lamine A, Caumont-Sarcos A, Chaix ML, Saez-Cirion A, Rouzioux C, Delfraissy JF, Pancino G, Lambotte O: Replication-competent HIV strains infect HIV controllers despite undetectable viremia (ANRS EP36 study). AIDS 2007, 21(8):1043-1045.

6. Julg B, Pereyra F, Buzon MJ, Piechocka-Trocha A, Clark MJ, Baker BM, Lian J, Miura T, Martinez-Picado J, Addo MM, Walker BD: Infrequent recovery of HIV from but robust exogenous infection of activated CD4(+) T cells in HIV elite controllers. Clin Infect Dis 2010, 51(2):233-238.

7. Bailey JR, O'Connell K, Yang HC, Han Y, XU J, Jilek B, Williams TM, Ray SC, Siliciano RF, Blankson JN: Transmission of human immunodeficiency virus type 1 from a patient who developed AIDS to an elite suppressor. J Virol 2008, 82(15):7395-7410.

8. Migueles SA, Sabbaghian MS, Shupert WL, Bettinotti MP, Marincola FM, Martino L, Hallahan CW, Selig SM, Schwartz D, Sullivan J, Connors M: HLA $B^{*} 5701$ is highly associated with restriction of virus replication in a subgroup of HIV-infected long term nonprogressors. Proc Natl Acad Sci USA 2000, 97(6):2709-2714.

9. Lambotte O, Boufassa F, Madec Y, Nguyen A, Goujard C, Meyer L, Rouzioux C, Venet A, Delfraissy JF, SEROCO-HEMOCO Study Group: HIV controllers: a homogeneous group of HIV-1-infected patients with spontaneous control of viral replication. Clin Infect Dis 2005, 41(7):1053-1056

10. Han Y, Lai J, Barditch-Crovo P, Gallant JE, Williams TM, Siliciano RF, Blankson JN: The role of protective HCP5 and HLA-C associated polymorphisms in the control of HIV-1 replication in a subset of elite suppressors. AIDS 2008, 22(4):541-544.

11. Emu B, Sinclair E, Hatano H, Ferre A, Shacklett B, Martin JN, McCune JM, Deeks SG: HLA Class I-Restricted T Cell Responses May Contribute to the Control of HIV Infection, but Such Responses are Not Always Necessary for Long-term Virus Control. J Virol 2008.

12. Pereyra F, Addo MM, Kaufmann DE, Liu Y, Miura T, Rathod A, Baker B, Trocha A, Rosenberg R, Mackey E, Ueda P, Lu Z, Cohen D, Wrin T, Petropoulos CJ, Rosenberg ES, Walker BD: Genetic and immunologic heterogeneity among persons who control HIV infection in the absence of therapy. J Infect Dis 2008, 197(4):563-571.

13. Migueles SA, Osborne CM, Royce C, Compton AA, Joshi RP, Weeks KA Rood JE, Berkley AM, Sacha JB, Cogliano-Shutta NA, Lloyd M, Roby G, Kwan R, McLaughlin M, Stallings S, Rehm C, O'Shea MA, Mican J, Packard BZ, Komoriya A, Palmer S, Wiegand AP, Maldarelli F, Coffin JM, Mellors JW, Hallahan CW, Follman DA, Connors M: Lytic granule loading of CD8+ T cells is required for HIV-infected cell elimination associated with immune control. Immunity 2008, 29(6):1009-1021.

14. Sajadi MM, Constantine NT, Mann DL, Charurat M, Dadzan E, Kadlecik P, Redfield RR: Epidemiologic characteristics and natural history of HIV-1 natural viral suppressors. J Acquir Immune Defic Syndr 2009, 50(4):403-408.

15. Migueles SA, Laborico AC, Imamichi H, Shupert WL, Royce C, McLaughlin M, Ehler L, Metcalf J, Liu S, Hallahan CW, Connors M: The differential ability of HLA B*5701+ long-term nonprogressors and progressors to restrict human immunodeficiency virus replication is not caused by loss of recognition of autologous viral gag sequences. J Virol 2003, 77(12):6889-6898.

16. Bailey JR, Williams TM, Siliciano RF, Blankson JN: Maintenance of viral suppression in HIV-1-infected HLA-B*57+ elite suppressors despite CTL escape mutations. J Exp Med 2006, 203(5):1357-1369.

17. Miura T, Brockman MA, Schneidewind A, Lobritz M, Pereyra F, Rathod A, Block BL, Brumme ZL, Brumme CJ, Baker B, Rothchild AC, Li B, Trocha A Cutrell E, Frahm N, Brander C, Toth I, Arts EJ, Allen TM, Walker BD: HLAB57/B*5801 human immunodeficiency virus type 1 elite controllers select for rare gag variants associated with reduced viral replication capacity and strong cytotoxic T-lymphotye recognition. J Virol 2009, 83(6):2743-2755

18. Navis M, Schellens I, van Baarle D, Borghans J, van Swieten P, Miedema F, Kootstra N, Schuitemaker H: Viral replication capacity as a correlate of 
HLA B57/B5801-associated nonprogressive HIV-1 infection. J Immunol 2007, 179(5):3133-3143.

19. O'Connell KA, Brennan TP, Bailey JR, Ray SC, Siliciano RF, Blankson JN: Control of HIV-1 in elite suppressors despite ongoing replication and evolution in plasma virus. J Virol 2010, 84(14):7018-7028.

20. Kiepiela P, Ngumbela K, Thobakgale C, Ramduth D, Honeyborne I, Moodley E, Reddy S, de Pierres C, Mncube Z, Mkhwanazi N, Bishop K, van der Stok M, Nair K, Khan N, Crawford H, Payne R, Leslie A, Prado J, Prendergast A, Frater J, McCarthy N, Brander C, Learn GH, Nickle D, Rousseau C, Coovadia H, Mullins Jl, Heckerman D, Walker BD, Goulder P. CD8+ T-cell responses to different HIV proteins have discordant associations with viral load. Nat Med 2007, 13(1):46-53.

21. Bailey JR, Brennan TP, O'Connell KA, Siliciano RF, Blankson JN: Evidence of CD8+ T-cell-mediated selective pressure on human immunodeficiency virus type 1 nef in HLA-B*57+ elite suppressors. J Virol 2009, 83(1):88-97.

22. Nei M, Gojobori T: Simple methods for estimating the numbers of synonymous and nonsynonymous nucleotide substitutions. Mol Biol Evol 1986, 3(5):418-426

23. Tamura K, Dudley J, Nei M, Kumar S: MEGA4: Molecular Evolutionary Genetics Analysis (MEGA) software version 4.0. Mol Biol Evol 2007, 24(8):1596-1599.

24. Migueles SA, Laborico AC, Shupert WL, Sabbaghian MS, Rabin R, Hallahan CW, Van Baarle D, Kostense S, Miedema F, McLaughlin M, Ehler L, Metcalf J, Liu S, Connors M: HIV-specific CD8+ T cell proliferation is coupled to perforin expression and is maintained in nonprogressors. Nat Immunol 2002, 3(11):1061-1068.

25. Betts MR, Nason MC, West SM, De Rosa SC, Migueles SA, Abraham J, Lederman MM, Benito JM, Goepfert PA, Connors M, Roederer M, Koup RA: HIV nonprogressors preferentially maintain highly functional HIV-specific CD8+ T cells. Blood 2006, 107(12):4781-4789.

26. Saez-Cirion A, Lacabaratz C, Lambotte $O$, Versmisse P, Urrutia A, Boufassa F, Barre-Sinoussi F, Delfraissy JF, Sinet M, Pancino G, Venet A, Agence Nationale de Recherches sur le Sida EP36 HIV Controllers Study Group: HIV controllers exhibit potent CD8 T cell capacity to suppress HIV infection ex vivo and peculiar cytotoxic T lymphocyte activation phenotype. Proc Natl Acad Sci USA 2007, 104(16):6776-6781.

27. Saez-Cirion A, Sinet M, Shin SY, Urrutia A, Versmisse P, Lacabaratz C, Boufassa F, Avettand-Fenoel V, Rouzioux C, Delfraissy JF, Barre-Sinoussi F, Lambotte O, Venet A, Pancino G, ANRS EP36 HIV Controllers Study Group: Heterogeneity in HIV suppression by CD8 T cells from HIV controllers: association with Gag-specific CD8 T cell responses. J Immunol 2009, 182(12):7828-7837.

28. Hersperger AR, Pereyra F, Nason M, Demers $K$, Sheth $P$, Shin LY, Kovacs CM, Rodriguez B, Sieg SF, Teixeira-Johnson L, Gudonis D, Goepfert PA, Lederman MM, Frank I, Makedonas G, Kaul R, Walker BD, Betts MR: Perforin expression directly ex vivo by HIV-specific CD8 T-cells is a correlate of HIV elite control. PLoS Pathog 2010, 6(5):e1000917.

29. Martinez-Picado J, Prado JG, Fry EE, Pfafferott K, Leslie A, Chetty S, Thobakgale C, Honeyborne I, Crawford H, Matthews P, Pillay T, Rousseau C, Mullins Jl, Brander C, Walker BD, Stuart DI, Kiepiela P, Goulder P: Fitness cost of escape mutations in p24 Gag in association with control of human immunodeficiency virus type 1. J Virol 2006, 80(7):3617-3623.

30. Brockman MA, Schneidewind A, Lahaie M, Schmidt A, Miura T, Desouza I, Ryvkin F, Derdeyn CA, Allen S, Hunter E, Mulenga J, Goepfert PA, Walker BD, Allen TM: Escape and compensation from early HLA-B57-mediated cytotoxic T-lymphocyte pressure on human immunodeficiency virus type $1 \mathrm{Gag}$ alter capsid interactions with cyclophilin A. J Virol 2007, 81(22):12608-12618.

31. Leslie AJ, Pfafferott KJ, Chetty P, Draenert R, Addo MM, Feeney M, Tang Y, Holmes EC, Allen T, Prado JG, Altfeld M, Brander C, Dixon C, Ramduth D, Jeena P, Thomas SA, St John A, Roach TA, Kupfer B, Luzzi G, Edwards A, Taylor G, Lyall H, Tudor-Williams G, Novelli V, Martinez-Picado J, Kiepiela P, Walker BD, Goulder PJ: HIV evolution: CTL escape mutation and reversion after transmission. Nat Med 2004, 10(3):282-289.

32. Crawford H, Prado JG, Leslie A, Hue S, Honeyborne I, Reddy S, van der Stok M, Mncube Z, Brander C, Rousseau C, Mullins JI, Kaslow R, Goepfert P, Allen S, Hunter E, Mulenga J, Kiepiela P, Walker BD, Goulder PJ:

Compensatory mutation partially restores fitness and delays reversion of escape mutation within the immunodominant HLA-B*5703-restricted Gag epitope in chronic human immunodeficiency virus type 1 infection. J Virol 2007, 81(15):8346-8351.
33. Leslie A, Kavanagh D, Honeyborne I, Pfafferott K, Edwards C, Pillay T, Hilton L, Thobakgale C, Ramduth D, Draenert R, Le Gall S, Luzzi G, Edwards A, Brander C, Sewell AK, Moore S, Mullins J, Moore C, Mallal S, Bhardwaj N, Yusim K, Phillips R, Klenerman P, Korber B, Kiepiela P, Walker B, Goulder P: Transmission and accumulation of CTL escape variants drive negative associations between HIV polymorphisms and HLA. J Exp Med 2005, 201(6):891-902.

34. Dinoso JB, Kim SY, Siliciano RF, Blankson JN: A comparison of viral loads between HIV-1-infected elite suppressors and individuals who receive suppressive highly active antiretroviral therapy. Clin Infect Dis 2008, 47(1):102-104.

35. Hatano H, Delwart EL, Norris PJ, Lee TH, Dunn-Williams J, Hunt PW, Hoh R, Stramer SL, Linnen JM, McCune JM, Martin JN, Busch MP, Deeks SG: Evidence for persistent low-level viremia in individuals who control human immunodeficiency virus in the absence of antiretroviral therapy. J Virol 2009, 83(1):329-335.

36. Pereyra F, Palmer S, Miura T, Block BL, Wiegand A, Rothchild AC, Baker B, Rosenberg R, Cutrell E, Seaman MS, Coffin JM, Walker BD: Persistent lowlevel viremia in HIV-1 elite controllers and relationship to immunologic parameters. J Infect Dis 2009, 200(6):984-990.

doi:10.1186/1742-4690-7-94

Cite this article as: Salgado et al:: Evolution of the HIV-1 nef gene in HLA-B*57 Positive Elite Suppressors. Retrovirology 2010 7:94.

\section{Submit your next manuscript to BioMed Central and take full advantage of:}

- Convenient online submission

- Thorough peer review

- No space constraints or color figure charges

- Immediate publication on acceptance

- Inclusion in PubMed, CAS, Scopus and Google Scholar

- Research which is freely available for redistribution

Submit your manuscript at www.biomedcentral.com/submit
C Biomed Central 